\title{
Antiproliferative and apoptotic activity of crude skin secretion from Malaysian Toad (Bufo asper) on in vitro colorectal cancer cells
}

\author{
Saad Sabbar Dahham ${ }^{\mathrm{a}^{*}}$, Muhammad Asif ${ }^{\mathrm{a}}$, Yasser M Tabana ${ }^{\mathrm{a}}$, Doblin Sandai ${ }^{\mathrm{b}}$, Amin Malik Shah Abdul Majid, \\ Gam Lay Harn ${ }^{\mathrm{a}}$ \\ ${ }^{a}$ School of Pharmaceutical Sciences, Universiti Sains Malaysia, 11800 Penang, Malaysia. \\ ${ }^{\mathrm{b}}$ Infectomics Cluster, Advanced Medical and Dental Institute, Universiti Sains Malaysia, 13200 Bertam, Penang, Malaysia.
}

\section{ARTICLE INFO}

Article history:

Received on: 21/07/2016

Revised on: 17/09/2016

Accepted on: 25/10/2016

Available online: $31 / 01 / 2017$

Key words:

Bufo asper, apoptotic,

anticancer, colorectal cancer.

\begin{abstract}
Earlier, a protein profile of Bufo asper skin secretion had been identified. The crud skin extract possessed antimicrobial activity against wide range of pathogenic bacteria. In the present communication, the antiproliferative and apoptogenic properties of toad's skin secretion (TSS) have been evaluated in colorectal cancer cell line. The antiproliferative activity of TSS was tested over HCT 116 and CCD-18Co cells by 3-(4,5Dimethylthiazol-2-yl)-2,5-Diphenyltetrazolium Bromide (MTT )assay. Hoechst and rhodamine staining and caspases 3 and 7 were evaluated in order to verify cell death and apoptosis. TSS exhibited potent dosedependent cytotoxic effect against human colorectal cancer cell line HCT 116 cells with an $\mathrm{IC}_{50}(15 \pm 1.19$ $\mu \mathrm{g} / \mathrm{mL}$ ). Conversely, the viability of normal colonic fibroblasts cell line CCD-18Co was much less affected by similar doses of TSS. Morphological studies by microscope on HCT 116 cells indicated certain events of apoptosis such as nuclear shrinkage, membrane blebbing and vacuolization of cells. This was further supported by activation of caspases 3 and 7. Considering the growing interest of developing naturally occurring hostdefense peptides for new anticancer agents, data presented in this work strongly reinforce the validity of Bufo asper skin secretion as a rich source of new anticancer compounds.
\end{abstract}

\section{INTRODUCTION}

Colorectal cancer (CRC) also known as colon cancer, is a malignant epithelial neoplastic arising from the colonic or rectal mucosa, results from a multi-step process leading to uncontrolled cell growth, proliferation and tumor progression. In spite of many advances in treatment, it remains as one of the most aggressive rampant killer across the world (Tabana et al., 2016). In Malaysia CRC recorded to be the first common cancer among the men and the second most common cancer diagnosed after the breast cancer among the women. In 2006, a total of 2,866 new cases were reported by Malaysian National Cancer Registry and represent $13.2 \%$ of all cancer cases (Omar et al., 2006). Currently, therapeutic approaches for CRC include radiotherapy, chemotherapy and surgery. However, conventional strategies for the treatment of this cancer are not yet satisfactory. Unfortunately, the cytotoxicity properties of the

* Corresponding Author

Email: hawk_dijla @yahoo.com most chemotherapeutic drug are nonspecific and therefore do not distinguish between normal healthy cells and tumor cells. These events have led to a wide range of side effects that limit the optimal effective doses leading to therapeutic failure (Rosenberg $e t$ al., 2004). Hence there is an urgent demand for safe and effective cancer therapeutics in addition to the implementation of new therapeutic options for the management of CRC mandates to understand the hallmark of CRC tumorigenesis with an emphasis on the mechanisms leading to chemotherapeutic resistance and tumor progression. One of the hallmarks of cancers is the resisting in the cell death process including apoptosis. Apoptosis is highly sophisticated and tightly regulated mechanism, involving an energy-dependent cascade of molecular events (Elmore, 2007). In general, the number of cells in any tissue is controlled by an equilibrium process between cell proliferation and cell death. Imbalance of this control is another essential hallmark of cancer cells (Tyson and Novak, 2014). The role of defective apoptotic machinery in the initiation of adenoma to carcinomas transformation in CRC has been reported by numerous studies (Huerta et al., 2006; Koehler et al., 2014). 
Although a number of new pharmacological components have recently entered clinical trials, the discovery of new sources of natural agents with anticancer properties that can selectively induce apoptosis in the cancer cells is still a challenge for the pharmaceutical industry. Hence, amphibians can become an important source of these lead compounds. Many host defense peptides offer high selectivity against cancer cells with no side effect on normal mammalian cells.

These peptides generally characterized by great structural diversity, cationic nature and a substantial portion of hydrophobic amino acids (Schweizer, 2009). The skin secretion of anurans (toad or/and frog) has been employed in therapeutic applications by many different cultures around the world. Toads, particularly genus Bufo, are well known to be a convenient and rich source of granular gland secretions, which normally contain biogenic amines, alkaloids and steroids, peptides and proteins (Maciel et al., 2003).

These biomolecules play a potential role in the development of new molecular approaches for pharmacological and toxicological evaluations and even for synthesis and medicinal chemistry (Ferreira et al., 2013). Earlier from this laboratory, it was found that the skin extract of Bufo asper possessed significant antimicrobial activity. Proteomic analysis of the skin secretions revealed more than 50 proteins were identified with a molecular weight ranging from 20 to $250 \mathrm{kDa}$ (Dahham et al., 2016). In the present study, further detail studies have been carried out on the anticancer activities of toad skin secretion (TSS) against colorectal cancer.

\section{MATERIAL AND METHODS}

\section{Materials}

Growth medium (RPMI 1640 and DMEM) trypsin, phosphate buffer saline (PBS) and heat/inactivated fetal bovine serum (HIFBS) were purchased from Gibco, UK. Caspase Glo 3/7 kits were purchased from Promega. Trypsin, DMSO and MTT 3(4 5-dimethylthiazol-2-yl)-2 5-diphenyltetrazolium bromide) were purchased from Sigma (St. Louis, USA.

\section{Collection of skin secretion}

Five Asian giant toads Bufo asper (mass range 60-70 g) were collected from Penang-Malaysia. Skin secretions were collected and immersed in crushed ice for $3 \mathrm{~min}$ and moistened with deionized water prior the stimulation of dorsal glands, then subjected to mild electrical stimulation using a bipolar electrode of platinum (10 -20 V DC and pulse duration of 3 minutes) at multiple sites on dorsal surface of the skin with electrodes. Skin secretions were washed from the specimen with deionized water $(50 \mathrm{~mL})$ and then lyophilized. All animals were returned to their habitat unharmed.

\section{Cell lines and culture conditions}

Human colorectal carcinoma cell line HCT 116 (catalogue number CCL-247) and normal colonic fibroblasts cell line CCD-18Co (catalogue number CRL-1459) wereprocured from ScienCell, USA. HCT-116 was maintained in RPMI and CCD$18 C$ o was maintained in DMEM medium. The media were supplemented with $5 \%$ heat, inactivated fetal bovine serum and $1 \%$ penicillin/streptomycin. Cells were cultured in a humidified incubator at $37{ }^{\circ} \mathrm{C}$ supplied by $5 \% \mathrm{CO}_{2}$.

\section{Cell Viability Assay}

The viability of the colorectal cancer cell line (HCT-116) as well as normal colonic fibroblasts cell line (CCD-18Co) was determined by MMT assay according to the method previously described (Dahham et al., 2014). Cells were seeded at $1.5 \times 10^{4}$ cells in each well of a 96-well plate in $100 \mu \mathrm{l}$ of fresh culture medium and were allowed to attach for overnight. Serial concentration ( 3.25 to $200 \mu \mathrm{g} / \mathrm{mL}$ ) of (TSS) was added to the cells accordingly.

After $48 \mathrm{~h}$ of the treatment the medium was aspirated and the cells were exposed to MTT solution prepared at $5 \mathrm{mg} / \mathrm{mL}$ in sterile PBS, which was added to each well at $10 \% \mathrm{v} / \mathrm{v}$ in the respective medium and incubated at $37^{\circ} \mathrm{C}$ in $5 \% \mathrm{CO}_{2}$ for $3 \mathrm{~h}$. The water insoluble formazan salts was solubilized with $200 \mu \mathrm{L}$ DSMO/well. Absorbance was measured by infinite ${ }^{\circledR}$ Pro200 TECAN Group Ltd., (Switzerland) at a primary wavelength of 570 $\mathrm{nm}$ and a reference wavelength of $620 \mathrm{~nm}$. Each plate contained the samples, negative control and blank. DMSO (1\% v/v) was used as a negative control. 5-fluorouracil was used as standard reference control.

The assay was performed in triplicate and the results were presented as a mean percent inhibition to the negative control, $(n=3)$.

\section{Caspase 3/7 Induction Detection}

Effect of (TSS) on caspase 3/7 was carried out according to the manufacturer's protocol Glo Kit (Promega). In brief, HCT116 cells $(4 \times 104$ cells $/ \mathrm{mL})$ were seeded in $100 \mu \mathrm{L}$ medium in a 96-well plate. After 24 hours, the cells were incubated with TSS of 10 and $20 \mu \mathrm{g}$; 5-fluorouracil $10 \mu \mathrm{g}$ and 1\% DMSO for 4 hours. Subsequently, Caspase reagent was added, and the activity was measured using a luminescent micro plate Infinite M200 PRO (Tecan Group Ltd.). The results were expressed as the fold changes in the caspase activity compared to the negative control were then determined $(n=3)$.

\section{Determination of nuclear condensation}

The effect of the TSS extract on nuclear chromatin condensation for HCT-116 cells was quantified using Hoechst 33258 stain according to the method (Dahham et al., 2016). The cell line was treated with the TSS extracts of 10 and $20 \mu \mathrm{g} / \mathrm{mL}$, for 6 and $12 \mathrm{~h}$. DMSO (1\%) was used as negative controls. The cells were fixed in $4 \%$ paraformaldehyde for $20 \mathrm{~min}$ before staining with Hoechst stain $33342(1 \mu \mathrm{g} / \mathrm{mL}$ in PBS) for another $20 \mathrm{~min}$. Nuclear morphology was examined under a fluorescent microscope. Cells with brightly colored, condensed, or fragmented nuclei were considered as apoptotic. The number of cells with 
apoptotic morphology was counted in randomly selected fields per well. The cells were photographed at 20x magnification of IX71 fluorescent microscope equipped with a digital camera (Olympus, Japan). The morphological changes of treated cells were evaluated by studying 5 randomly selected microscopic fields, and the apoptotic index was calculated for each microscopic field using the formula

Apoptotic Index $=$ (the number of apoptotic cells $/$ the total cell count) $\times 100 \%$

The results are presented as mean $\pm \mathrm{SD}$.

\section{Detection of mitochondrial membrane potential loss}

Detection of the changes in mitochondrial membrane potential in HCT 116 cells treated with TSS extract was assessed by the retention of Rhodamine 123 fluorescent dye following previous protocol (Dahham et al., 2015). Normally, the dye interacts with the inner mitochondrial negatively charged membrane and accumulates in normal mitochondria, but the reduction of mitochondrial membrane leads to the dye leakage which will result in reducing the fluorescence intensity. In this study, the cells were separately seeded in 6 well plates and incubated overnight. The cells were treated with the TSS extract at a concentration of 10 and $20 \mu \mathrm{g} / \mathrm{mL}$, for 6 and 12 hours intervals and then fixed using $4 \%$ paraformaldehyde for $20 \mathrm{~min}$. DMSO (1\%) was used as negative controls Rhodamine 123 was added to the cells at a final concentration of $5 \mathrm{mg} / \mathrm{mL}$ and incubated for 30 min to stain the mitochondria. The wells then were photographed at at 20x magnification of IX71 fluorescent microscope equipped with a digital camera (Olympus, Japan). The morphological changes of treated cells were evaluated by studying 5 randomly selected microscopic fields, and the apoptotic index was calculated for each microscopic field using the formula

Apoptotic Index $=$ (the number of apoptotic cells $/$ the total cell count) $\times 100 \%$

The results are presented as mean $\pm \mathrm{SD}$.

\section{Statistical analysis}

Statistical analysis was performed by one-way analysis of variance (ANOVA) followed by Tukey's multiple comparison test. Statistical significance was considered at $p<0.05$ and $p<$ 0.01 and were indicated as $*$ and $* *$, respectively.

\section{RESULTS}

\section{Effect of TSS on cell viability}

Antiproliferative effect of TSS was tested against colorectal cancer cell line (HCT 116) and normal colonic fibroblasts cell line (CCD-18Co) using MTT assay. As shown in Fig 1, TSS inhibited HCT 116 cells in a dose/dependent manner. Analysis of the dose/response curves indicates strong cytotoxic effect with a median inhibitory concentration $\mathrm{IC}_{50}$ of $15 \pm 1.19$ $\mu \mathrm{g} / \mathrm{mL}$. On the other hand, TSS displayed moderate cytotoxicity against normal colonic fibroblasts cell line CCD-18Co with an $\mathrm{IC}_{50}$ of $28.4 \pm 2.35 \mu \mathrm{g} / \mathrm{mL}$.
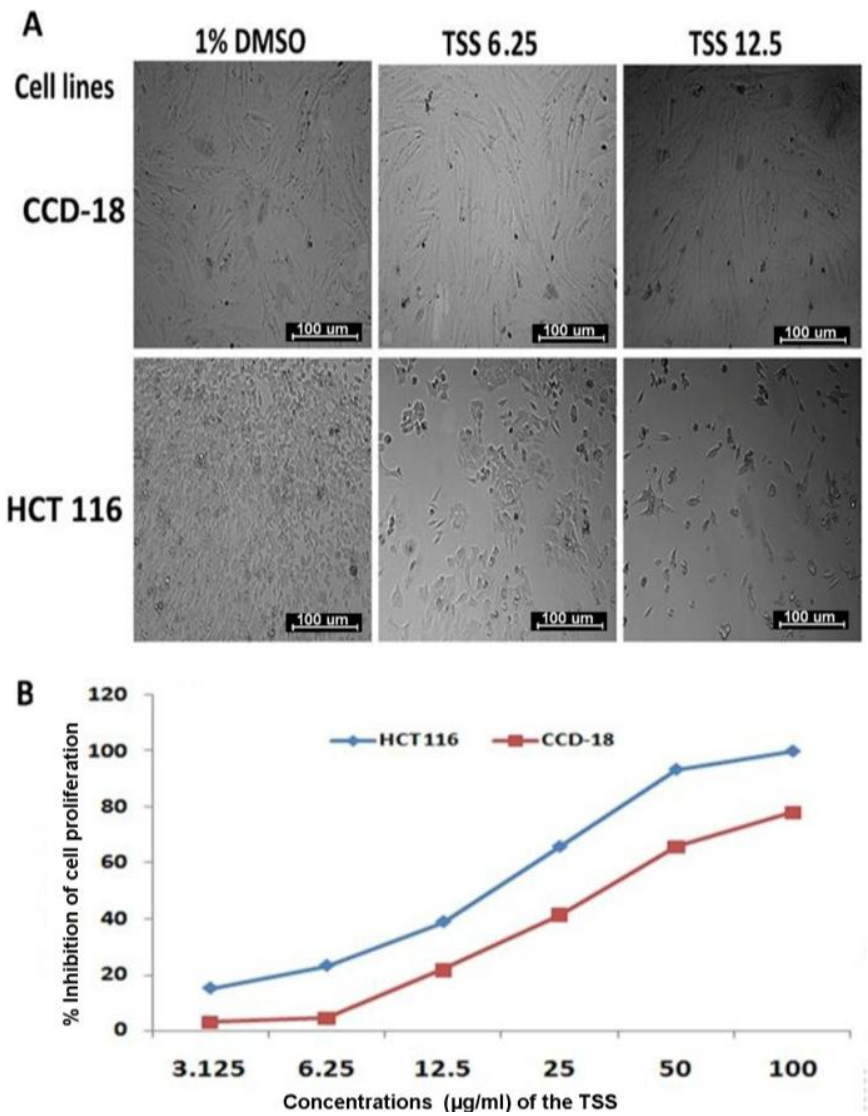

Fig 1: Effect of TSS on cellular morphology of CCD-18Co and HCT 116 cells (A) Photomicrographic images were taken under an inverted phase-contrast microscope at 200x magnification using a digital camera at $48 \mathrm{~h}$ after. Cells treated with $1 \%$ DMSO revealed an aggressive proliferation, whereas the treatment with TSS at 6.25 and $12.5 \mu \mathrm{g} / \mathrm{ml}$ showed obvious inhibition for HCT 116 and less cytotoxicity against CCD-18Co. (B) Dose-dependent antiproliferative effect of TSS on CCD-18Co and HCT 116 cell lines were assessed by MTT-assay.

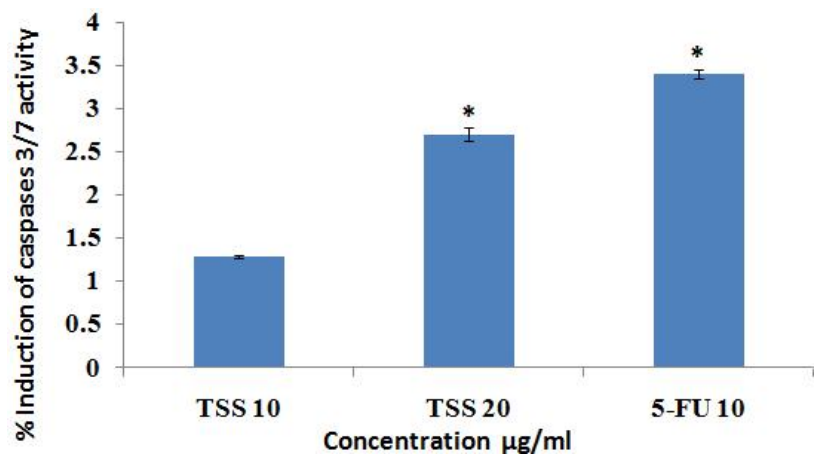

Fig 2: The dose/dependent stimulatory effect of TSS on the caspase 3/7 level after 4 hours of treatment

\section{TSS Activated Caspase 3/7 in HCT 116 Cells}

In this study, activity of the executioner caspases was significantly induced by treating HCT 116 cells with TSS in dose/dependent manner as shown in Fig 2. Compared to untreated cells, treatment with TSS at 10 and $20 \mu \mathrm{g} / \mathrm{mL}$ for 4 hours displayed significant enhancement of the caspase activity by $1.2 \pm$ 
0.2 and $2.7 \pm 0.4$ fold, respectively. 5-Fluorouracil at $10 \mu \mathrm{g} / \mathrm{mL}$ induced the caspase activity by $3.4 \pm 0.3$ fold.

\section{Effect of TSS on mitochondrial membrane potential and nuclear morphology}

In order to measure the apoptotic pathway induced by the TSS, the mitochondrial membrane potential in HCT 116 cells was examined by visualizing the uptake of the lipophilic cation dye Rhodamine 123 by mitochondria. Microscopic examination revealed the strong intensity of fluorescence in the untreated cells (Fig 3A), indicates the aggressive growth and proliferation of the cells, whereas the signal dropped significantly in the cells treated with TSS in a time/dependent manner. The apoptotic index estimated for TSS $(10 \mu \mathrm{g} / \mathrm{mL})$ after 6 and 12 hours treatment was $15.8 \pm 3 \%$ and $32.2 \pm 3.7 \%$ respectively. The apoptotic index at 20 $\mu \mathrm{g} / \mathrm{mL}$ after 6 and 12 hours treatment was $23.1 \pm 2.5 \%$ and $45.9 \pm$ $3.6 \%$, respectively (Fig $\mathbf{3 B})$.
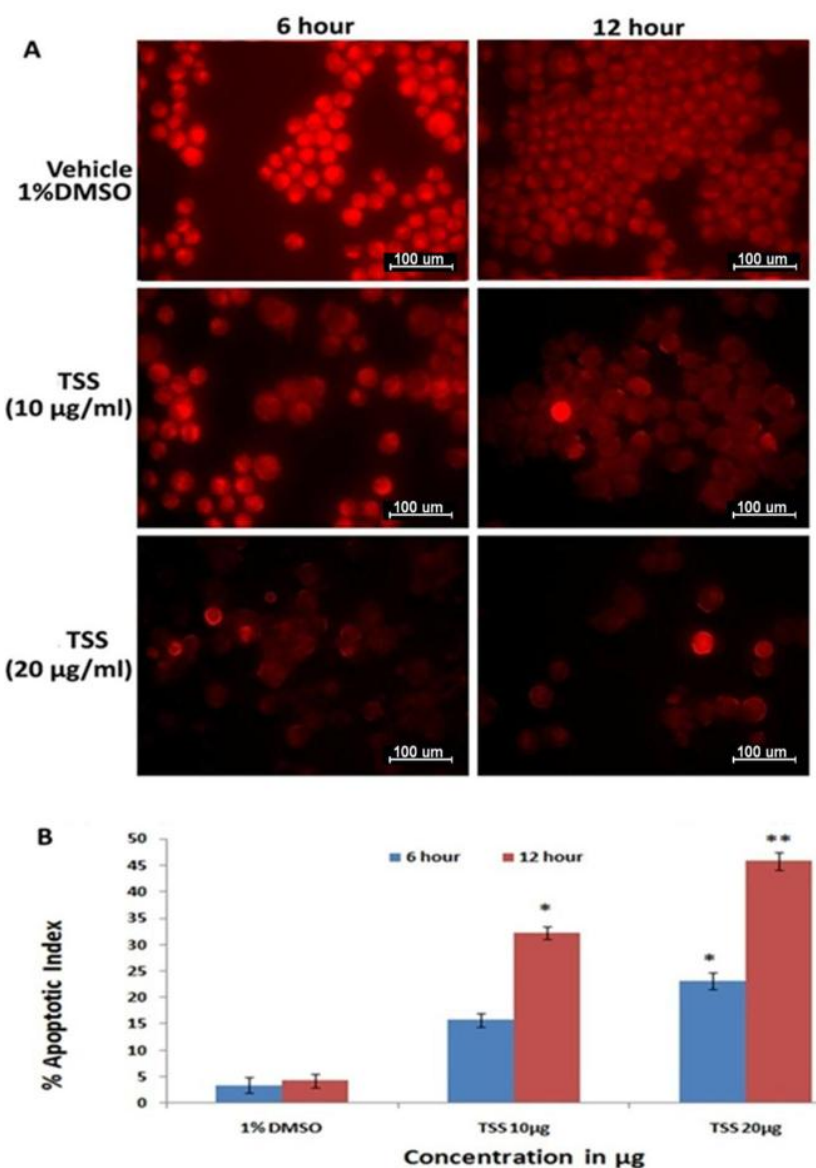

Fig 3: (A) The photomicrographs depict the effect of TSS on the mitochondrial membrane potential of HCT 116 cells by Rhodamin 123 assay, taken under an inverted phase-contrast microscope at 200x magnification using a digital camera at 6 and $12 \mathrm{~h}$ after treatment with TSS. (B) Graphical representation of the percentage of apoptotic indices. The apoptotic index was expressed as a percentage of the ratio of a number of unstained cells to the total number of cell in 10 different microscopic fields. Values are presented as mean $\pm \operatorname{SD}(n=10)$, $\left(^{*}=\mathrm{p}<0.05\right.$ and $\left.* *=p<0.01\right)$.

On the other hand, staining of HCT 116 cells with Hoechst 33258 resulted in morphological alteration appearance of treated cells with TSS. Fig. 4A illustrates that the untreated cells with DMSO showed normal nuclei morphology characterized by aggressive growth and compact layer of cells with weak intensity fluorescence. After 6 hours treatment with TSS, the cells started displaying the early stage of apoptosis such as condensed nuclei, irregularly distributed chromatin and crescent-shaped nuclei. The advance stage of apoptosis was indicated after $12 \mathrm{~h}$ treatment with clear signs of nuclear shrinkage and discrete apoptotic bodies (Fig 4 A). The apoptotic index of TSS $(10 \mu \mathrm{g} / \mathrm{mL})$ after 6 and $12 \mathrm{~h}$ treatment was $17.8 \pm 3.2 \%$ and $30.2 \pm 4 \%$, respectively. Whilst for $20 \mu \mathrm{g} / \mathrm{mL}$ at 6 and 12 hours, the treatment was increased to $26.2 \pm$ $2.4 \%$ and $49.9 \pm 3 \%$, respectively (Fig 4 B).

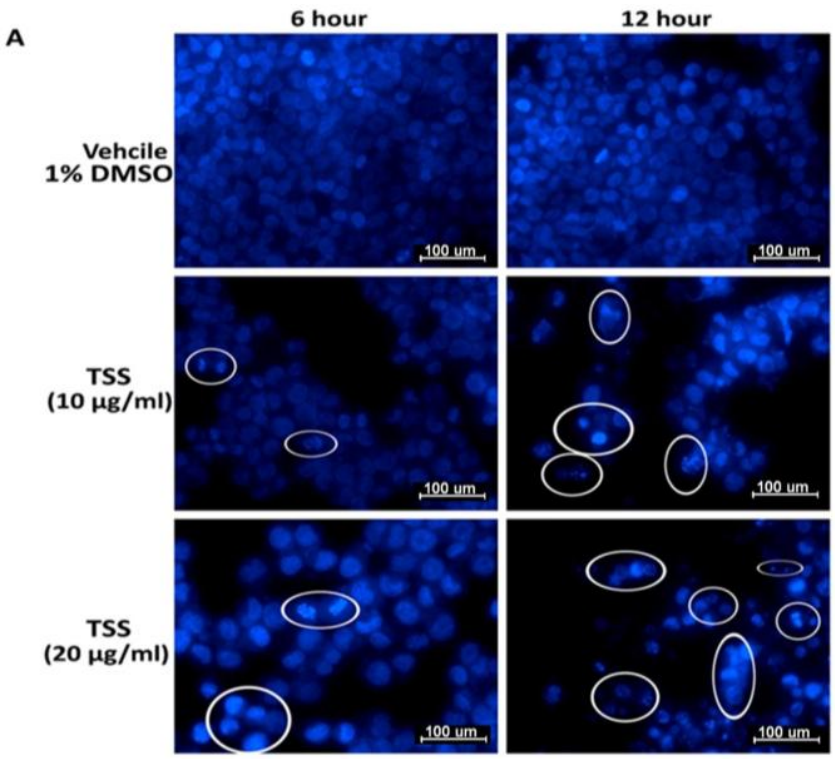

B

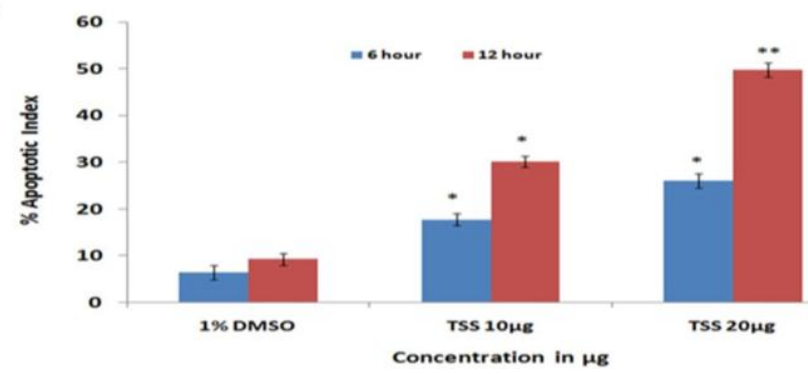

Fig 4: The photomicrographs depict the images HCT 116 cells with Hoechst 33258 stain, under an inverted phase-contrast microscope at $200 \mathrm{x}$ magnification using a digital camera at 6 and 12 hours after treatment with TSS. (A) The cells treated with 1\% DMSO (Vehicle) showed an intact cell membrane with prompt and evenly distributed nucleus in the cytosol, whereas cells treated with $10 \mu \mathrm{g} g / \mathrm{mL}$ TSS after $6 \mathrm{~h}$ displayed early stage apoptotic such as membrane blebbing and chromatin condensation .Subsequently, the cells treated with TSS after 12 hours revealed late staged apoptotic produced clear single like nuclear dissolution and crescent shaped apoptotic nuclei. The circled cells indicate the early and late stage of apoptotic events. (B) Graphical representation of the percentage of apoptotic indices HCT 116 cells. The apoptotic index was expressed as a percentage of the ratio of a number of apoptotic cells to the total number of cell in 10 different microscopic fields. Values are presented as mean $\pm \operatorname{SD}(n=10),(*=p<0.05$ and $* *=p<0.01)$.

\section{DISCUSSION}

Amphibian skins and their derivatives serve as an intriguing source of potent therapeutic against a certain type of 
cancer cells (Sciani et al., 2013). Toads, particularly genus Bufo, are fascinating sources of active compounds, such as peptides, alkaloids, bufadienolides, biogenic amines and proteins. In the present study, TSS of Bufo asper exhibited potent dose/dependent antiproliferative activity, with an $\mathrm{IC}_{50}$ value of $15 \pm 1.19 \mu \mathrm{g} / \mathrm{mL}$. This result has demonstrated more inhibitory effect than the previous study on Indian toad Bufo melanostictus, which have reported the antiproliferative capacity against K562 and U937 cells with an $\mathrm{IC}_{50}$ value of $81.1-92.2$ and $55.0-66.2 \mathrm{mg} / \mathrm{mL}$, respectively (Giri et al., 2006). Interestingly, TSS was less toxic towards normal colonic fibroblasts cell line CCD-18Co with an $\mathrm{IC}_{50}$ value of $28.4 \pm 2.35 \mu \mathrm{g} / \mathrm{mL}$. In fact, the electrostatic differences between cancer cells and normal cells may explain the mechanism and selective toxicity criteria of TSS against HCT 116 cells. The outer membrane of malignant cells has been reported to carry an elevated negative charge of anionic molecules such as phosphatidylserine, O-glycosylated mucins and heparan sulfates, whereas the surface of normal mammalian cell membranes is typically zwitterionic in nature (Schweizer, 2009). Consequently, the presence of cationic peptides in amphibian skin secretions with their positive charges and amphipathic features may enhance the binding capability towards cancer cells by electrostatic interactions and hence lead to cytotoxicity of cancer cells (Chen et al., 2014; Conlon et al., 2013). Following the basis of cytotoxicity results, we have investigated the effect of TSS on the early and late stages of apoptosis process. TSS significantly stimulates the executioner caspases 3/7 indicating early signals of apoptosis which activates other series of morphological and biochemical hallmarks of cell death including nuclear condensation and degradation which were determined by the Hoechst 33342 assay.

The morphological alteration of the treated HCT 116 with 10 and $20 \mu \mathrm{g}$ of TSS shows conspicuous apoptotic events. The shrinkage of nucleus and disappearance of nucleoli signified the advanced stage of apoptosis (Kerr, 2002). Previous observation on the studies of Chinese toad Bufo gargarizans skin formulation (Chan Sue) was found to induce apoptosis in several human cancer cell lines such as (T24) human bladder carcinoma cells (Ko et al., 2005), (A549) human lung carcinoma (Yun et al., 2009). (HepG2) Hepatocarcinoma cells (Lu et al., 2011), (NHL) non-Hodgkin's lymphoma and (SP53) mantle cell lymphoma (Efuet et al., 2015). In order to obtain deeper insight into the apoptotic effect of TSS, the mitochondrial membrane potential was examined by staining the cells with lipophilic cationic dye rhodamine123 which can be easily absorbed by the mitochondria of live cells. It is well established that the loss of mitochondrial membrane potential is a hallmark sign of an early stage of apoptosis (Dahham et al., 2016). In this study, untreated HCT 116 cells with (1\% DMSO) showan intense fluorescent signal, whereas the fluorescent intensity decreased significantly in the cells treated with TSS in a dose and time/dependent manner (Fig 3). The result indicates that the uptake of lipophilic cationic dye was failed due to the loss of membrane potential in treated cells and thus eventually leads to apoptotic cell death. Indeed, induction of apoptosis in cancer cells is a recognized approach in cancer therapy (Khan et al., 2014;
Qiao et al., 2009). CRC is characterized by the partial inhibition of apoptosis, which in turn gives tumors a selective advantage for survival and can cause chemotherapy resistance. Recent progress in understanding the mechanisms of apoptosis in CRC has offered rational strategies for novel therapies (Yang et al, 2009).

The present work provides strong supporting evidence that toad skin secretion of bufo asper possesses significant antiproliferative activity against colorectal cancer cells. Further, the inhibitory effect of TSS was mediated through the apoptotic pathways as showed in (Fig 5).

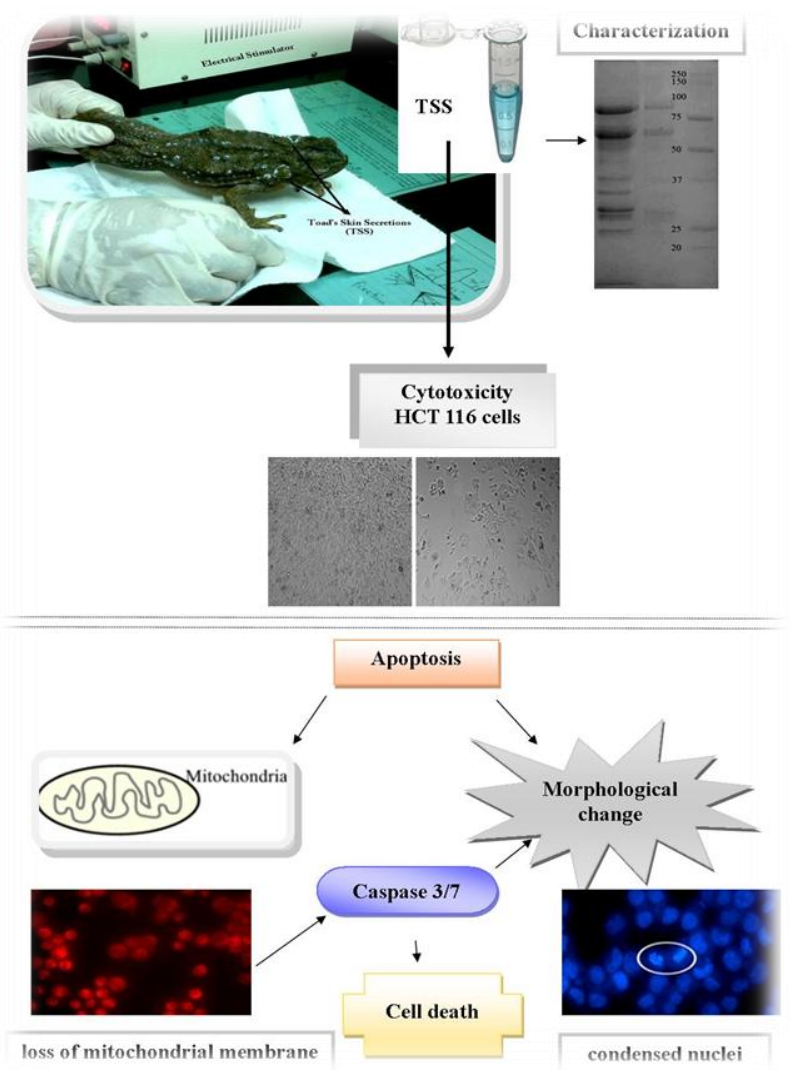

Fig 5: Schematic diagram of the cytotoxicity and apoptotic pathway induced by TSS in HCT 116 cells.

\section{CONCLUSION}

In conclusion, we analyzed the skin secretion of the toad Bufo asper for antiproliferative effect. The TSS exhibited significant activity towards HCT 116 cell line. The exact mechanism that causes inhibition in cell viability and cytotoxicity after treatment with the TSS is still unknown. Nevertheless, we found strong evidence of apoptosis-mediated cell death and further studies are necessary to validate the apparent biochemical and morphological changes in HCT 116 cells. Further studies are also necessary to purify the active principle protein or/and peptide molecules responsible for the observed activity on cancer cells.

\section{Financial support and sponsorship: Nil.}

Conflict of Interests: There are no conflicts of interest. 


\section{REFERENCES}

Chen $\mathrm{C}, \mathrm{Hu}$ J, Zeng P, Pan F, Yaseen M, Xu H, Lu JR. Molecular mechanisms of anticancer action and cell selectivity of short $\alpha$ helical peptides. Biomaterials 2014;35:1552-61.

Conlon JM, Mechkarska M, Prajeep M, Arafat K, Zaric M, Lukic ML, Attoub S. Transformation of the naturally occurring frog skin peptide, alyteserin-2a into a potent, non-toxic anti-cancer agent. Amino acids 2013; 44:715-23.

Dahham SS, Ahamed MBK, Saghir SM, Alsuede FS, Iqbal MA, Majid AMSA. Bioactive essential oils from Aquilaria crassna for cancer prevention and treatment. Glob J Adv Pure Appl Sci 2014; 4:1-6.

Dahham SS, Al-Rawi SS, Ibrahim AH, Majid AS, Majid AM. Antioxidant, anticancer, apoptosis properties and chemical composition of black truffle Terfezia claveryi. SAUDI J BIOL SCI 2016.

Dahham SS, Hew CS, Jaafar I, Gam LH. THE PROTEIN PROFILING OF ASIAN GIANT TOAD SKIN SECRETIONS AND THEIR ANTIMICROBIAL ACTIVITY. Int J Pharm Pharm Sci 2016; 8:88-95.

Dahham SS, Tabana YM, Hassan LE, Ahamed MB, Majid AS, Majid AM. In vitro antimetastatic activity of Agarwood (Aquilaria crassna) essential oils against pancreatic cancer cells. Alexandria J.Med $2016 ; 52: 141-50$

Dahham SS, Tabana YM, Iqbal MA, Ahamed MB, Ezzat MO, Majid AS, Majid AM. The Anticancer, Antioxidant and antimicrobial properties of the sesquiterpene $\beta$-caryophyllene from the essential oil of Aquilaria crassna. Molecules 2015;20:11808-29.

Efuet ET, Ding XP, Cartwright C, Pan Y, Cohen L, Yang P. Huachansu mediates cell death in non-Hodgkin's lymphoma by induction of caspase-3 and inhibition of MAP kinase. Int J Oncol. 2015;47:592-600.

Elmore S. Apoptosis: a review of programmed cell death. Toxicol Pathol 2007; 35:495-516.

Ferreira PM, Lima DJ, Debiasi BW, Soares BM, da Conceição Machado K, da Costa Noronha J, de Jesus Rodrigues D, Sinhorin AP, Pessoa C, Júnior GM. Antiproliferative activity of Rhinella marina and Rhaebo guttatus venom extracts from Southern Amazon. Toxicon 2013; 72:43-51.

Giri B, Gomes A, Debnath A, Saha A, Biswas AK, Dasgupta SC. Antiproliferative, cytotoxic and apoptogenic activity of Indian toad (Bufo melanostictus, Schneider) skin extract on U937 and K562 cells. Toxicon 2006; 48:388-400.

Huerta S, Goulet EJ, Livingston EH. Colon cancer and apoptosis. Am J Surg 2006; 191:517-26.

Kerr JF. History of the events leading to the formulation of the apoptosis concept. Toxicology 2002; 181:471-4.

Khan KH, Blanco-Codesido M, Molife LR. Cancer therapeutics: Targeting the apoptotic pathway. Crit Rev Oncol Hematol 2014;90:200-19.

Ko WS, Park TY, Park C, Kim YH, Yoon HJ, Lee SY, Hong $\mathrm{SH}$, Choi BT, Lee YT, Choi YH. Induction of apoptosis by Chan Su, a traditional Chinese medicine, in human bladder carcinoma T24 cells. Oncol Rep. 2005; 14:475-80.
Koehler BC, Jager D, Schulze-Bergkamen H. Targeting cell death signaling in colorectal cancer: current strategies and future perspectives. World J Gastroenterol 2014; 20: 1923-34.

Lu CX, Wang WY, Ma N, Cui Y, Li XY, Zhou Y. Anticancer peptide from Chinese toad (Bufo Bufo Gargarizans) skin enhanced sensitivity to 5-Fu in hepatocarcinoma cells (HepG2). Clin Oncol. Cancer Res. 2011; 8: 149-54.

Maciel NM, Schwartz CA, Junior OR, Sebben A, Castro MS, Sousa MV, Fontes W, Schwartz EN. Composition of indolealkylamines of Bufo rubescens cutaneous secretions compared to six other Brazilian bufonids with phylogenetic implications. Comp. Biochem. Physiol. B Biochem. Mol Biol 2003;134:641-9.

Omar ZA, Ali ZM, Tamin NS. Malaysian Cancer StatisticsData and Figure, Peninsular Malaysia 2006. National cancer registry, ministry of health Malaysia 2006.

Qiao L, Wong BC. Targeting apoptosis as an approach for gastrointestinal cancer therapy. Drug Resist Updat 2009;12:55-64.

Rosenberg SA, Yang JC, Restifo NP. Cancer immunotherapy: moving beyond current vaccines. Nature Med 2004; 10:909-15.

Schweizer F. Cationic amphiphilic peptides with cancerselective toxicity. Eur J Pharmacol 2009;625:190-4

Sciani JM, de-Sá-Júnior PL, Ferreira AK, Pereira A, Antoniazzi MM, Jared C, Pimenta DC. Cytotoxic and antiproliferative effects of crude amphibian skin secretions on breast tumor cells. Biomed Prevent Nutr 2013; 3:10-8

Tabana YM, Dahham SS, Shah AM, Majid A. Major Signaling Pathways of Colorectal Carcinogenesis. Recent Advances in Colon Cancer 2016; 1: 1-2.

Tyson JJ, Novak B. Control of cell growth, division and death: information processing in living cells. Interface focus 2014; 4:20130070.

Yang SY, Sales KM, Fuller B, Seifalian AM, Winslet MC. Apoptosis and colorectal cancer: implications for therapy. Trends Mol Med 2009; 15:225-33

Yun HR, Yoo HS, Shin DY, Hong SH, Kim JH, Cho CK, Choi YH. Apoptosis induction of human lung carcinoma cells by Chan $\mathrm{Su}$ (Venenum Bufonis) through activation of caspases. J Acupunct Meridian Stud. 2009;2:210-7.

\section{How to cite this article:}

Dahham SS, Asif M, Sandai D, Majid AMA, Harn GL. Antiproliferative and apoptotic activity of Crude Skin Secretion from Malaysian Toad (Bufo asper) on in vitro colorectal cancer cells. J App Pharm Sci, 2017; 7 (01): 001-006. 